\title{
URBAN DEVELOPMENT AND INTEGRATED COASTAL ZONE MANAGEMENT IN THE BAY OF CADIZ
}

\author{
MARIA DE ANDRES \& JUAN M. BARRAGAN \\ University of Cadiz, Spain
}

\begin{abstract}
Coastal areas record a clear process of demographic concentration. This process is of great importance in Spanish coastal zones, where cities and agglomerations develop the majority of economic activities. Moreover, the coastal zone is the region where vulnerable coastal-marine ecosystems are located.

The Bay of Cadiz is a clear example of this development model. The terrestrial, marine and intertidal area of this bay has a surface of 44349 ha, and covers six municipalities: Rota, El Puerto de Santa María, Puerto Real, Chiclana, San Fernando and Cádiz. The population of this area is mainly urban, and amounts more than 400,000 inhabitants. Moreover, all of these municipalities, except Rota, are involved in a protected area: Natural Park Bay of Cadiz.

This protected area presents singular characteristics; on the one hand, because of the quantity of coastal ecosystems and habitats in these intertidal areas, on the other hand, due to the great influence of human development modifying the environment. Growth of cities in this area has associated an increase of infrastructures and urban facilities on coastal and marine ecosystems, causing fragmentation and loss of important ecosystem services.

The communication developed is focused on the study of the Bay of Cadiz as a social-ecological system, where the development of cities and infrastructures, and the ecosystem diversity, cause the necessity of an integrated management in these coastal areas.

Keywords: urban areas, Bay of Cadiz, Natural Park, ecosystem services, ICZM.
\end{abstract}

\section{INTRODUCTION}

Coastal areas are suffering a clear process of demographic concentration, in which coastal cities play a role of great importance [1], [2]. This is the cause of the loss of the services that coastal ecosystems provide to human wellbeing [1]. In Spain, coastal zone is configured as one of the most important areas for population and economy. Moreover, the Spanish National Ecosystem Assessment highlights that coastal ecosystems are degraded faster and more intensively than others [3]. Besides, one of the mail drivers of change is the transformation of land use [4]. The impact that this driver of change produce on coastal ecosystems is particularly pronounced in urban areas [5], [6], and especially in the Bay of Cadiz, where ecosystems and urban population are in high contact.

The natural environment of the Bay is characterized by the complex land-sea interaction. The extent and variety of floodplain in the form of fangs, marshes, estuaries and salt marshes has conditioned from its origins both the urban structure of the network and the land uses. The morphology of the different settlements is characterized by the coastal location of the population centres. Urban soils and intertidal areas are bounded and separated successively. The declaration as Natural Park and the conditions imposed by the Law of Coasts definitively mark the urban system as a set of cities separated by intertidal zones. The sectorial legislations ensure their conservation and preservation facing urban activities.

The present study focuses on the achievement of the following objectives: analysis of the cities of the Bay of Cadiz, as well as the development of urban population in the last decades. In addition, the development of infrastructures and equipment associated with the urban 
environment and the services that coastal ecosystems provide to society were studied. The Natural Park Bay of Cadiz stands out as a conservation and management instrument for the most vulnerable ecosystems to the pressures of surrounding urban centres.

\section{INFORMATION SOURCES AND METHOD}

\subsection{Information sources}

The analysed information in this research come from different type of sources: a) bibliographic, analysing previous studies; b) statistical, from population census; and c) maps, from shapefiles. The Spanish National Statistics Institute provided information about municipalities and population. The urban characteristics were obtained from different shapefiles and statistical information: data of urban areas (Spanish Urban Areas Method) [7]; the Demarcation of the Maritime-Terrestrial Public Domain (Ministry of Agriculture, Food and Environment); the coastline (Spanish Navy Hydrographical Service); the boundaries of Bay of Cadiz municipalities (National Statistics Institute).

Information about urban land uses in the Bay of Cadiz were obtained from the Land Uses Map of Andalusia [8], which account geographic information for 1956 and 2007 at 1:25,000 scale. The Land Uses Map of Andalusia has an accurate database about thematic and geometrical information. These maps are classified in 166 land uses, of which we selected 11 classes with urban characteristics.

\subsection{Study method}

The method developed for study had three different stages:

- Cities and population in the Bay of Cadiz: this stage consisted in analysing the evolution of population in every municipality of Bay of Cadiz and the importance of urban centres and their infrastructures. Firstly, population census were analysed from 1960 to 2015 in every municipality. The second step was to study the evolution of infrastructures associated to urban development. For this purpose, an analysis of Land Uses Map in a Geographic Information System (QGIS 2.16 Nodebo) from 1956 to 2007 was developed. Moreover, an updated shapefile of urban infrastructures in 2015 was created.

- Ecosystem types: the second stage was to study the coastal ecosystems in the Bay of Cadiz. Also, the services for each ecosystem were obtained and classified in the four international categories: support, provision, regulation and cultural [9].

- Bay of Cadiz Natural park: the last step consisted in considering the importance of a protected area in the study area, which management allow developing the socioeconomic sector of the urban population. The management instruments of this Natural Park will provide an opportunity for the conservation of coastal ecosystems and their services.

\section{RESULTS}

\subsection{Cities and population in the Bay of Cadiz}

The Bay of Cadiz in a formal sense (as reflected in the Land Planning regional document) includes the municipalities of Cadiz, San Fernando, Chiclana, Puerto Real and El Puerto de Santa María. Although, from a socio-economic point of view, part of the municipalities of Rota and Jerez de la Frontera could be incorporated. On the other hand, the geographic and 
physical-natural characteristics allow including the municipality of Rota in this analysis. In this sense, the municipalities considered in the investigation are Cadiz, San Fernando, Chiclana, Puerto Real, Puerto de Santa María and Rota, taking into account also the socioeconomic characteristics of Jerez de la Frontera and its influence in the Bay of Cadiz.

The Bay is the main urban concentration of the south-Atlantic coast of the Peninsula. Its population size, position, port facility and productive activity confirm the potentiality in the urban network of the southernmost part of Europe.

The evolution of the population in the municipalities of the Bay of Cadiz has meant an increase of the pressures and the impacts that occur on the coastal ecosystems, intensified in the last 60 years [10]. The evolution of the population in each municipality is shown below (Table 1).

Table 1: $\quad$ Municipalities in the Bay of Cadiz and evolution of population between 1960 and 2015.

\begin{tabular}{|l|l|l|l|l|l|}
\hline Municipalities & 1960 & 1980 & 2000 & 2007 & 2015 \\
\hline Cádiz & 11,4951 & 15,6711 & 14,0061 & 12,8554 & 12,0468 \\
\hline Chiclana & 21,947 & 36,492 & 55,398 & 65,584 & 70,114 \\
\hline El Puerto de Santa María & 35,610 & 55,748 & 71,921 & 79,785 & 80,680 \\
\hline Puerto Real & 18,108 & 23,890 & 29,534 & 38,121 & 40,511 \\
\hline San Fernando & 47,423 & 72,103 & 88,179 & 95,026 & 96,131 \\
\hline Rota & 15,690 & 20,559 & 25,393 & 26,889 & 28,340 \\
\hline
\end{tabular}

Fig. 1 shows that Cadiz is the one that has housed and houses the largest population. Similarly, it is the only municipality that has declined in population in the last 60 years, contrary to what happens with the other municipalities of the Bay of Cadiz, which have all increased their population in the study period.

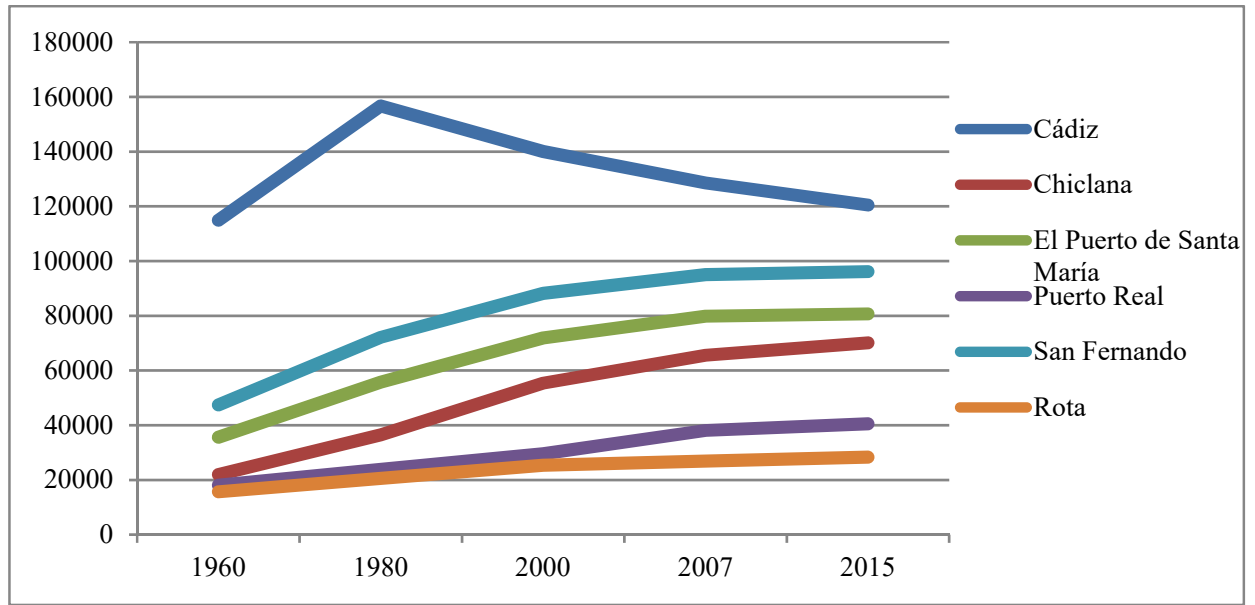

Figure 1: Evolution of population in the Bay of Cádiz. Comparison among different municipalities. 
As for the population density of every municipality, the high density of Cadiz stands out with 9531 inhabitants $/ \mathrm{km}^{2}$ followed by San Fernando with 3144 inhabitants $/ \mathrm{km}^{2}$, while the municipalities of Puerto de Santa María (550 inhabitants $/ \mathrm{km}^{2}$ ), Chiclana de la Frontera (376 inhabitants $/ \mathrm{km}^{2}$ ) and Puerto Real (205 inhabitants $/ \mathrm{km}^{2}$ ) have a lower population density. In these cases, as will study in the following section, the distribution of the population within the municipality is unequal, attending mainly to economic and social factors.

\subsection{Urban development and their infrastructures in the Bay of Cadiz}

The urban development of the Bay of Cadiz in the last decades has meant an exponential land occupation because of the expansion of existing urban centres, and the creation of large residential urban areas, with a pattern of construction more dispersed. This is a characteristic of the urbanizations for tourist activity. In this regard, the analysis obtained that the 1000 hectares occupied by urban centres in 1960 increased to over 8000 hectares occupied by 2015. Therefore, the change of land uses is manifested in the Bay of Cadiz as the main pressure of coastal ecosystems.

In the study of urban occupation in the different municipalities of the case study, it is noted that Cadiz and San Fernando have exhausted their soils due to their own geography. The truth is that, in general terms, the natural system limits urban expansion. The rest of municipalities have suffered the pressures of a rapid and disrupted urbanization process. In the 1960 the construction of low-density residential centres began on the coast, which, over time, have become largely in main housing, although they still depend functionally on city centres. In addition, there has been a significant occupation of the interior space by illegal houses and constructions [11]. This has resulted in a strong landscape modification and significant environmental impacts.

In addition, this urban development has led to the development of infrastructures and equipment that the population demands (Table 2). However, due to the geographic characteristics of the Bay, this development of infrastructures occurs in most cases on vulnerable coastal ecosystems, especially marshes, since they are practically the only free spaces of the environment, which favours their drainage and the infrastructures and urban equipment construction.

Table 2: Hectares occupied by urban infrastructures in 1960 and 2015.

\begin{tabular}{|l|c|c|}
\hline Occupied hectares & 1960 & 2015 \\
\hline Infrastructures (mainly roads) & 377.12 & 1364.32 \\
\hline Port areas & 85.88 & 242.03 \\
\hline Shipping and offshore infrastructures & 70.27 & 308.52 \\
\hline Industrial areas & 71.93 & 988.28 \\
\hline Tourist services & 6.21 & 485.75 \\
\hline Urban equipment & 55.09 & 424.18 \\
\hline
\end{tabular}

Fig. 2 shows the development of road and rail infrastructures as the type of infrastructure that has most modified the Bay of Cadiz. Some examples of coastal ecosystems and marshes occupation by road infrastructures is observed in the construction of the Cádiz-San Fernando highway (Fig. 3) and the access to Cadiz by the Trocadero (Fig. 4). In addition, the recent construction of the Constitution Bridge to access Cadiz leads to a major modification and expansion of the road network in the municipalities of Cadiz and Puerto Real. 


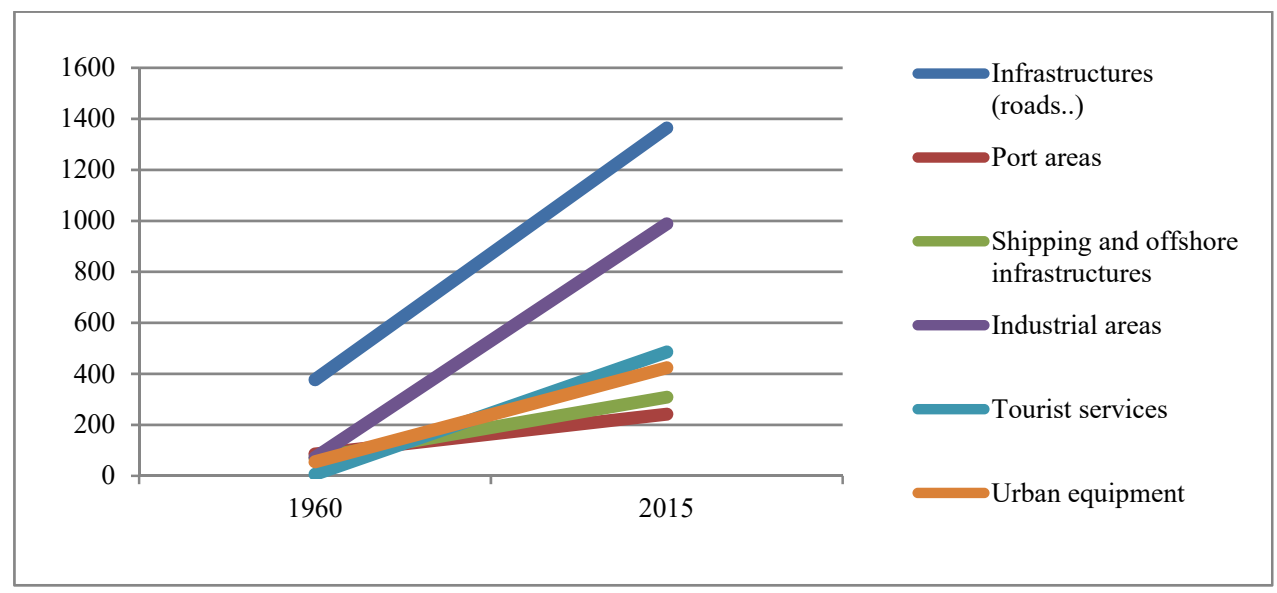

Figure 2: Evolution of urban infrastructures between 1960 and 2015.

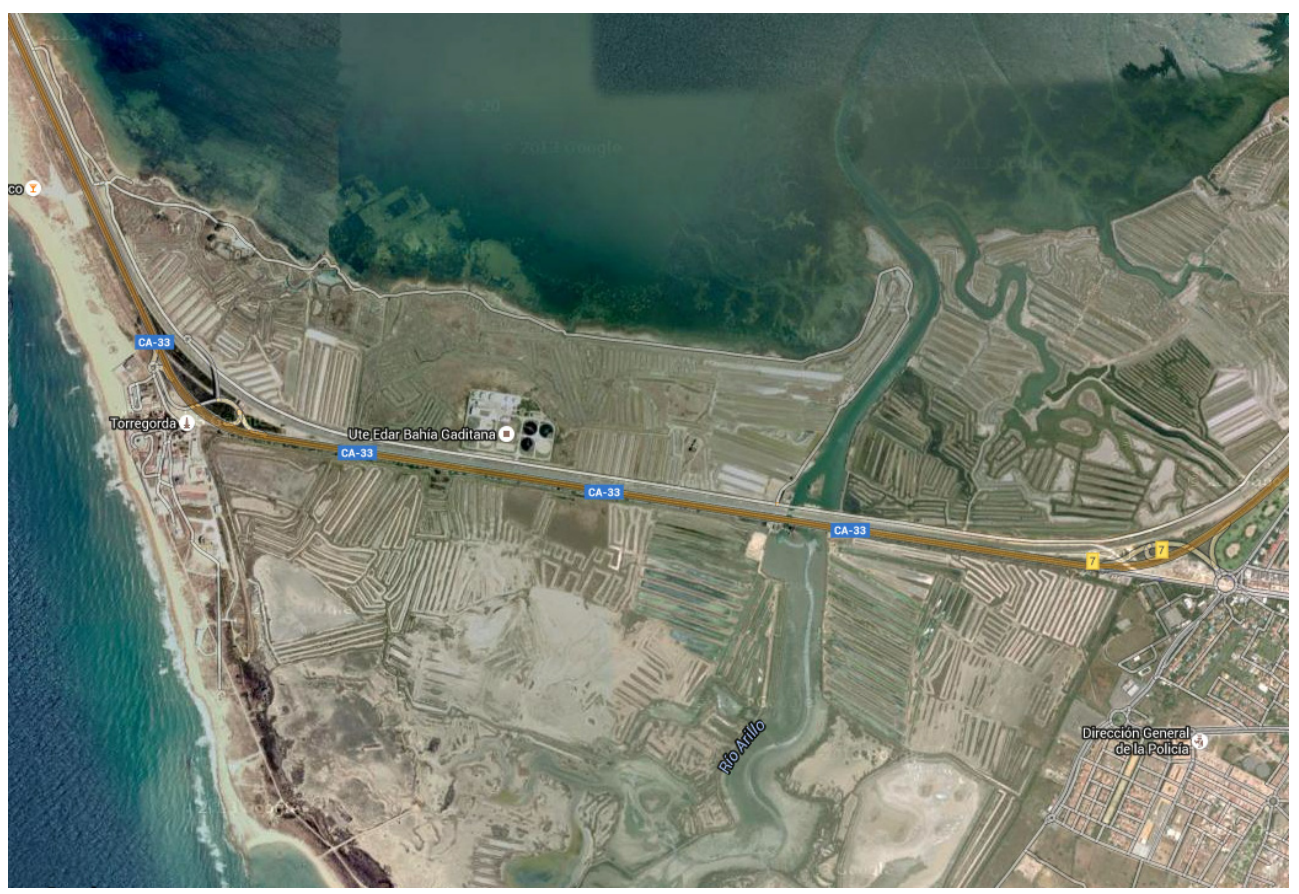

Figure 3: Cádiz-San Fernando highway over saltmarshes. (Source: Google Earth.) 


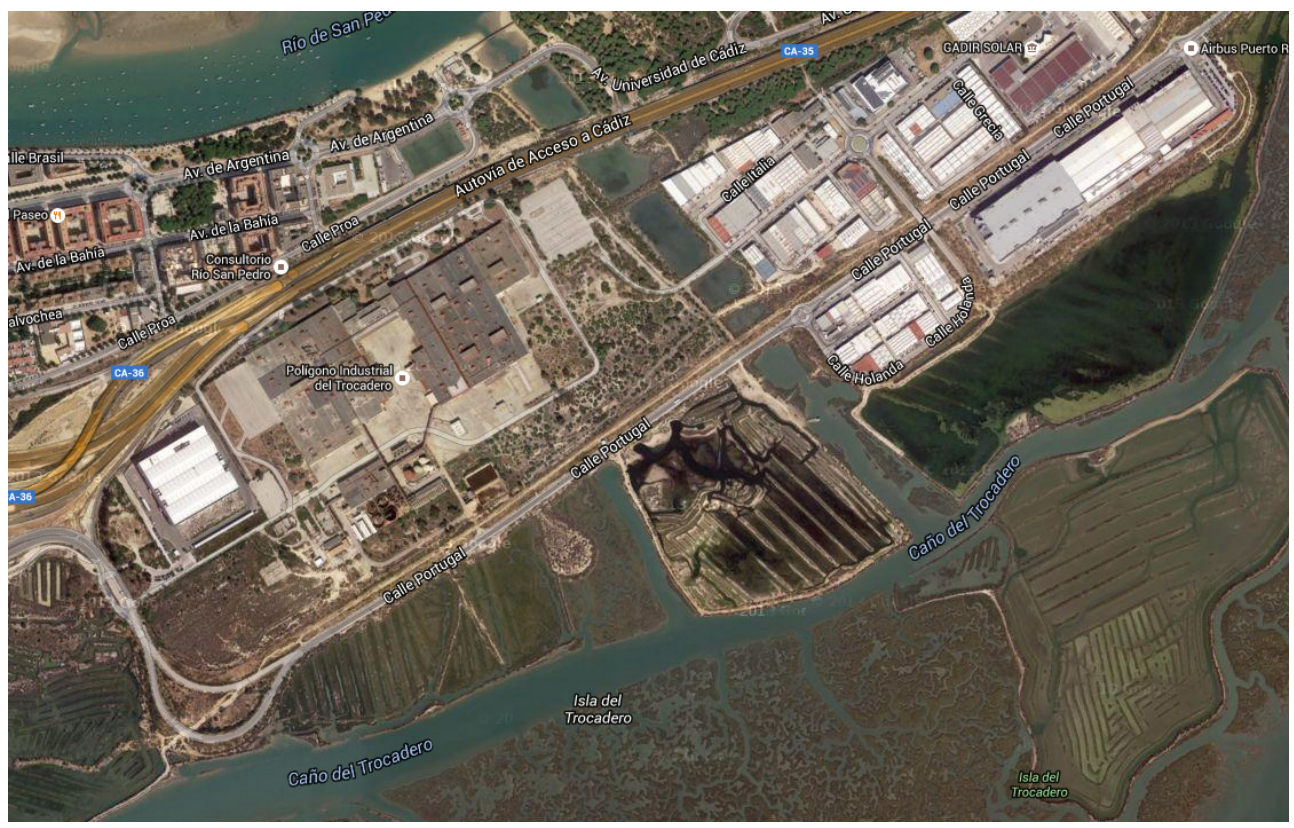

Figure 4: Highway access to Cádiz from the Trocadero. (Source: Google Earth.)

In addition to the road infrastructures, there are other types of infrastructures and facilities that have been built on saltmarshes and salt lakes in the last decades. Regarding industrial areas, the development of polygons such as Fadricas and Fadricas II in San Fernando stands out, the latter still unfinished since 2007. In terms of urban facilities, the construction in 1998 of the Cadiz-San Fernando water treatment plant over the salt lakes of the Bay of Cadiz Natural Park highlights. Also, the fire station of San Fernando was built in on the saltmarshes adjacent to the urban centre. In terms of university facilities, there is a progressive construction of the campus of Puerto Real on the land adjacent to the Natural Park since the 1990 and with an expansion in the last years (2014).

In the municipality of Rota, it is necessary to emphasize the importance of the installation of the Naval Base in the fifties for the population and infrastructure development since its installation [12]. Thus, although in the short term the creation of the base was a spectacular growth of the population and economy, in the long term has led to saturation of the ecosystem and the economic dependence.

As a result, it is observed that the urban development on the Bay of Cadiz, although not presenting a population increases as high as in other coastal provinces of Spain (Malaga or Valencia), has a marked multi nuclear character that entails the construction of infrastructures and equipment allowing the development of all urban centres. The problem resides in the occupation of vulnerable coastal ecosystems for the construction and development of these infrastructures and facilities.

\subsection{Ecosystem types in the Bay of Cadiz}

The physical-natural characteristics of the Bay of Cadiz and its associated ecosystems are for its geography and topography. The Bay of Cadiz is characterized by the presence of the 
estuary of the Guadalete River. The characteristics of a flat topography favour the development of large extensions of tidal saltmarshes. In the inner bay there are several beaches such as La Puntilla, Valdelagrana and Levante, as well as coastal forests in the dunes of San Antón and La Algaida in Puerto Real. In the outside of the bay there is a sandy coast from Cadiz to the Sancti Petri River in Chiclana.

The saltmarshes and the Guadalete estuary are located in transition zones between the marine and terrestrial environments. Saltmarshes are lowlands, protected from marine forces, where fine sediments settle. The main characteristic of saltmarshes is the confluence of fresh and salt water. Its location on the coastline, but sheltered from the open sea, causes variations of salinity, conditioning the existing biological communities [13]. At the same time, the marine waters under the action of the tides enter the saltmarshes and develop a set of rivers and channels. The saltmarshes of the Bay of Cadiz are modified in salt lakes that were used by the man for centuries. At present most of the salt lakes are abandoned or used for aquaculture productions. So in many cases, their abandonment is leading to the return of the salt lakes in natural saltmarshes; or to their drying, originating in this case unproductive soils. The survival of salt lakes means the conservation of a cultural and landscape heritage, as well as contributing to the maintenance of the biodiversity present in the Bay of Cadiz [12], [14].

As for the beaches, sandy beaches characterize the bay of Cadiz. The presence of the Guadalete estuary and its sedimentary contribution originates the accumulation of finer sediments on the beaches. It is possible to differentiate three different parts in these beaches: the submerged beach that is affected by the waves; the intertidal area that is the zone affected by the tides; and the emerged beach that is located between the intertidal area and the top of the beach.

The dunes of the bay of Cadiz are dunes of west, by their orientation [15]; they are in a flat coastline (beach of Valdelagrana, beach of Cortadura, beach of Camposoto). Dunes are developed after the beaches as there are no obstacles and the sand tends to settle. However, due to the intense occupation of these areas in the last decades, dunes have been reduced considerably in many areas.

Coastal forests are located in the interior of the coastal zone, after the beaches, dunes or marshes. The coastal pine forests of the Bay of Cadiz have their origin in repopulations made during the nineteenth Century. These repopulations were carried out in order to fix coastal dunes [16]. The coastal pine forests appear with other tree formations typical of the coastal environment.

The services offered by the coastal ecosystems in the Bay of Cadiz to society are multiple and with a different origin (support, supply, regulation and cultural) [4]. They are all highly impacted as a result of the loss of ecosystems due to urban development. Table 3 shows the services offered by the coastal ecosystems of the Bay of Cadiz grouped according to United Nations categories [9].

\subsection{Bay of Cadiz Natural Park as a coastal management instrument}

The Bay of Cadiz Natural Park occupies 10522 ha, which is almost $1 / 4$ of the Bay of Cadiz area; so its management and planning play a fundamental role in controlling the urban development pressures. Despite the high human pressure, almost intact areas are still remains. This is the case of Sancti Petri saltmarshes and the Trocadero Island. The important strategic and defensive value of this area influenced the early appearance, 3000 years ago, of human settlements in the Bay, which have let an exceptional cultural heritage. 
Table 3: Ecosystem services in the Bay of Cadiz ecosystems.

\begin{tabular}{|c|c|}
\hline Service types & Services \\
\hline \multirow{2}{*}{ Support } & Habitat \\
\hline & Transport infrastructures \\
\hline \multirow{4}{*}{ Provision } & Food \\
\hline & Raw materials \\
\hline & Biochemical \\
\hline & Fresh water \\
\hline \multirow{7}{*}{ Regulation } & Climate regulation \\
\hline & Water purification \\
\hline & Erosion control \\
\hline & Disturbance regulation \\
\hline & Pollination \\
\hline & Noise reduction \\
\hline & Air purification \\
\hline \multirow{7}{*}{ Cultural } & Education \\
\hline & Research \\
\hline & Recreational and \\
\hline & Aesthetic \\
\hline & Sense of place \\
\hline & Iconic species \\
\hline & Spiritual and religious \\
\hline
\end{tabular}

In the Bay of Cadiz Natural Park, various economic activities are regulated according to the singularity of the area. Aquaculture activities represent the main activity that takes place within this natural area. The aquaculture established in the area is based on the use of the old salt lakes as a marine farm for fishes. In addition, there are also molluscs farming located in the intertidal area. Nowadays, the high rates of fish production on farms in the Bay of Cadiz are generated by intensive and semi-intensive production systems. Extensive aquaculture on the other hand has lost profitability, which leads people who work there to improve profitability through improved extensive cultivation or by developing complementary activities associated with tourism such as on-site tasting.

Moreover, the salt extraction was one of the most important and emblematic economic activities of the Bay of Cadiz, favoured by the natural characteristics of the area, as well as by climatological factors that favour intense evaporation. Throughout the history of the salt industry, the Bay of Cadiz has experienced a succession of times of boom and crisis. During the nineteenth century there were the great phases of the salt lakes that built the current landscape of this protected area, reaching more than 140 salt lakes on an area of about 6000 hectares. However, various economic and technical causes, and radical decline in salt exports led to the abandonment of this activity [17].

The fishing activity is carried out outside the existing legal framework, so there is no official data about the fishing effort and the main fishing areas in the Natural Park. The same 
thing happens with the shellfish that in spite of not existing a register of this activity, studies estimate in about 200 regular people working on it.

As far as tourism is concerned, the Natural Park has great potential, not only as a driving force in this sector, but also as a means of enhancing the natural and cultural heritage of the area. With all this, it is observed that the management of the Bahía de Cádiz Natural Park is fundamental for the activation of a sustainable economy in the Bay. Moreover, it is necessary to enhance the value offered by the protected area to guarantee the conservation of its ecosystems, given the constant pressure of urban development presented by urban centres.

\section{CONCLUSION}

The Bay of Cadiz has suffered in the last decades an urbanization process in which free land areas have been saturated. This has propitiated the occupation of the intertidal area (saltmarshes and salt lakes mainly) for the construction of infrastructures and facilities necessary to supply the population. The development of compact and residential urban centres, coupled with the growth of urban infrastructures, causes a loss of coastal ecosystems and, consequently, the services that these ecosystems offer to society. The creation of the Bahía de Cádiz Natural Park was the control of urban development in most of the intertidal areas of the Bay, but it is necessary to encourage the valorisation of this area, and the development of economic activities compatible with the protected area, in order to guarantee the real conservation of the coastal ecosystems.

\section{REFERENCES}

[1] UNEP, Marine and coastal ecosystems and human well-being: a synthesis report based on the findings of the Millennium Ecosystem Assessment, 2006.

[2] Barragán, J.M. \& de Andrés, M., Analysis and trends of the world's coastal cities and agglomerations. Ocean Coast Manag, 114, pp. 11-20, 2015.

[3] Spanish National Ecosystem Assessment, Ecosystems and biodiversity for human wellbeing. Synthesis of the key finding, Biodiversity Foundation of the Spanish Ministry of Agriculture Food and Environment: Madrid, 2013.

[4] Barragán, J.M. \& Borja, F., Evaluación de los tipos operativos de ecosistemas-litorales, in Evaluación de los Ecosistemas del Milenio de España, Fundación Biodiversidad. Ministry of Agriculture Food and Environment, 2012, p. 1129.

[5] Agardy, T., et al., Coastal Systems, in Ecosystems and Human Well-being: Current Status and Trends, 2005, pp. 513-550.

[6] Lee, Y.-C., Ahern, J. \& Yeh, C.-T., Ecosystem services in peri-urban landscapes: The effects of agricultural landscape change on ecosystem services in Taiwan's western coastal plain. Landsc Urban Plan, 139, pp. 137-148, 2015.

[7] Ruiz, F., AUDES. Áreas Urbanas de España. Modelo y Método, 2011, http://alarcos.esi.uclm.es/per/fruiz/audes. Accessed on: 1 Jan. 2015.

[8] Moreira, J.M., Mapas de usos y coberturas vegetales del suelo de Andalucía. Escala 1/25000. Guía Técnica. Consejería de Medio Ambiente. Junta de Andalucía, Seville, 2007.

[9] MEA, Ecosystems and their services. Ecosystems and Human Well-being: A Framework Assessment, pp. 49-70, 2003.

[10] Garrido, M.A., Análisis de un área metropolitana litoral: Bahia de Cádiz. El uso de un Sistema de Información Geográfica para la gestión integrada, Universidad de Sevilla, 2000 . 
[11] Salgado, P. \& Casares, O., Lectura geográfica de la bahía de Cádiz: Singularidades y Conflictos, in Ambientes, Ventanas y Miradas de Paisajes de Andalucía y Marruecos, Ministry of Environment, Board of Andalusia: Seville, 2007, p. 22.

[12] Villalobos, C.A., Antropización histórica de un espacio natural Las salinas de la Bahía de Cádiz. Patrim Hist Andaluz, 35, pp. 172-185, 2001.

[13] García de Lomas, J., García, C.M., \& Álvarez, Ó., Vegetación de las marismas de Aletas-Cetina (Puerto Real). Identificación de hábitats de interés comunitario y estimaciones preliminares de posibles efectos de su inundación. Rev la Soc Gaditana Hist Nat, 5, pp. 9-38, 2006.

[14] Perez Hurtado, A. (coord), Salinas de Andalucia, Ministry of the Environment, Board of Andalusia: Seville, 2004.

[15] Artolachipi, A. \& Calvo, J., El litoral de la provincia de Cádiz. Manual para el profesor. Consejería de Medio Ambiente. Board of Andalusia, 2006.

[16] Martínez-Montes, E., Alejano Monje, R. \& Villalón, D., Los pinares de pino piñonero en el sur peninsular. Papel en la dinámica natural en base a la arqueología prehistórica y protohistórica. Nuevas interpretaciones. Cuad la Soc Española Ciencias For, 16, pp. 121-126, 2003.

[17] Plan de Ordenación de los Recursos Naturalesdel Parque Natural Bahía de Cádiz, in Decreto 79/2004, de 24 de febrero, por el que se aprueban el Plan de Ordenación de los Recursos Naturales y y el Plan Rector de Uso y Gestión del Parque Natural Bahía de Cádiz, Consejería de Medio Ambiente. Board of Andalusia, 2004, p. 102. 